\title{
PERSEPSI, EFEKTIFITAS DAN KEAMANAN PENGGUNAAN ROKOK ELEKTRIK (E-CIGARETTE) OLEH PEROKOK AKTIF SEBAGAI TERAPI DALAM SMOKING CESSATION: MIXED METHODS DENGAN PENDEKATAN STUDI KUANTITATIF DAN KUALITATIF
}

\author{
Amelia Lorensia $^{1, *}$, Ananta Yudiarso ${ }^{2}$, Findry Rafsanjani Herwansyah ${ }^{3}$ \\ ${ }^{1}$ Departement of Clinical-Community Pharmacy, Faculty of Pharmacy, Universitas Surabaya (UBAYA). Jl. \\ Raya Kalirungkut Surabaya \\ ${ }^{2}$ Departement of Phsicology Social, Faculty of Psychology, Universitas Surabaya (UBAYA). Jl. Raya \\ Kalirungkut Surabaya \\ ${ }^{3}$ Postgraduate Student of Faculty of Pharmacy, Universitas Surabaya (UBAYA). Jl. Raya Kalirungkut \\ Surabaya \\ *Correspondence author: amelia.lorensia@gmail.com; amelia.lorensia@staff.ubaya.ac.id
}

\begin{abstract}
Cigarettes is one of the biggest causes of health problems in the world. Disadvantages in terms of health and economy is then the program to stop smoking (smoking cessation) became the main choice of treatment for smokers. Now a lot of smokers switch to using electric cigarette (e-cigarette) which increased rapidly its development. This study aims to explore more deeply about the perception, effectiveness and safety of the use of electric cigarette by active smokers in their efforts to quit smoking. This research design uses mix method, with descriptive method stage and interpretive phase of phenomenology analysis (IPA) in observing perception, effectiveness, and security. Respondents involved as many as 47 people, namely users of electric cigarettes that had previously used regular cigarettes (tobacco). The results showed participants thought that electrically effective cigarettes help in the process of smoking cessation. Elastic cigarettes have been shown to reduce the frequency of tobacco use (25\%) and cause smoking cessation (75\%). While most respondents did not experience side effects (66.66\%), and the reported effects were dry and cough throat (33.33\%). In conclusion, electric cigarettes are believed to be able to help the smoking cessation process although its effectiveness and safety still require further research.
\end{abstract}

Keywords: perception, effectiveness, safety, cigarette electric, smoking cessation

\begin{abstract}
ABSTRAK
Rokok merupakan salah satu faktor penyebab gangguan kesehatan terbesar di dunia. Kerugian dalam hal kesehatan dan ekonomi tersebut maka program berhenti merokok (smoking cessation) menjadi pilihan utama pengobatan bagi perokok. Kini banyak perokok beralih menggunakan rokok elektrik (e-cigarette) yang meningkat pesat perkembangannya. Penelitian ini bertujuan untuk menggali lebih dalam mengenai persepsi, efektifitas dan keamanan penggunaan rokok elektrik oleh perokok aktif dalam usahanya untuk berhenti merokok. Desain penelitian ini menggunakan mix method, dengan tahap metode deskriptif dan tahap interpretatif phenomenologi analysis (IPA) dalam mengamati persepsi, efektifitas, dan keamanan. Responden yang terlibat sebanyak 47 orang, yaitu pengguna rokok elektrik yang sebelumnya pernah menggunakan rokok biasa (tembakau). Hasil penelitian menunjukkan partisipan menganggap rokok elektrik efektif membantu dalam proses smoking cessation. Rokok eletrik terbukti mengurangi frekuensi penggunaan rokok tembakau $(25 \%)$ dan menyebabkan berhenti merokok $(75 \%)$. Sedangkan sebagian besar responden tidak mengalami efek samping $(66,66 \%)$, dan efek yang dilaporkan adalah tenggorokan terasa kering dan batuk $(33,33 \%)$. Kesimpulannya rokok elektrik diyakini mampu membantu proses smoking cessation walaupun efektifitas dan keamanannya masih membutuhkan penelitian lebih lanjut.
\end{abstract}


Pengaruh ekstrak etanol daun jambu air (Syzygium aqueum (burm f.)Alston) terhadap glukosa darah, ureum dan kreatinin tikus putih (rattus norvegicus)

Kata Kunci: persepsi, efektifitas, keamanan, rokok elektrik, smoking cessation

Submitted on: 7 November 2017

Accepted on:21 December 2017

DOI: https://doi.org/10.25026/jtpc.v4i2.142

\section{PENDAHULUAN}

Rokok adalah ancaman kesehatan masyarakat di dunia yang menyebabkan kematian. Indonesia merupakan produsen terbesar kelima daun tembakau dan juga produsen dan eksportir rokok terbesar di dunia. Bahkan, Indonesia juga merupakan pengkonsumsi rokok terbesar ketiga di dunia [1].

Satu batang rokok yang dibakar mengandung banyak senyawa kimia yang memiliki sifat karsinogen berbahaya, dan tidak ada kadar minimal yang aman terhadap paparan asap tembakau [2]. Beberapa jenis penyakit yang dapat dipicu karena merokok antara lain seperti penyakit kardiovaskuler, penyakit pernafasan kronis, penyakit gangguan pencernaan, yang dapat menyebabkan kematian [3]. Merokok tidak hanya berbahaya bagi perokok sendiri, namun juga orang-orang di sekitar (perokok pasif) [4]. Selain menyebabkan gangguan kesehatan tubuh, rokok juga mempengaruhi kondisi ekonomi. Menurut Nasional Badan Pusat Statistik (2017) [5], bahwa sumbangan rokok pada GKM (Garis Kemiskinan Makanan) sebesar $8,08 \%$ (perkotaan) dan 7,68\% (pedesaan), memang jelas dapat dikatakan bahwa orang yang dikategorikan miskin ternyata banyak yang mengkonsumsi rokok. Bukan berarti orang yang tidak miskin tidak merokok, tetapi bagi mereka share pengeluaran rokok ini sangatlah kecil dibandingkan pengeluaran untuk barang-barang mewah lainnya.
Oleh karena kerugian dalam hal kesehatan dan ekonomi tersebut maka program berhenti merokok (smoking cessation) menjadi pilihan utama pengobatan bagi perokok. Walaupun telah banyak produk farmasi yang digunakan untuk berhenti merokok, namun hanya mampu membuat perokok berhenti sementara saja [6]. Hal ini disebabkan nikotin di dalam rokok yang menimbulkan efek ketergantungan. Nikotin merangsang reseptor asetilkolin pada neuron yang berisi dopamin, sehingga menyebabkan peningkatan dopamin di pusat brain reward system. Kadar puncak nikotin, aktivasi brain reward system yang sementara, diikuti dengan turunnya kadar nikotin secara bertahap, sampai pada suatu titik withdrawal yang hanya dapat dihilangkan dengan menghisap rokok. Nikotin menyebabkan perasaan menyenangkan yang membuat perokok ketagihan untuk terus merokok. Ketika para perokok berusaha mengurangi atau mencoba berhenti merokok, maka dapat memunculkan gejala kecemasan dan gelisah. Semakin lama kandungan nikotin yang berada dalam tubuh maka semakin kuat perilaku merokoknya, sehingga perokok semakin sulit untuk meninggalkan rokoknya [7-8]. Penelitian oleh Lorensia et al. [9], menunjukkan bahwa berhenti merokok adalah hal yang kompleks dan tidak mudah. Semua responden penelitian tersebut mengalami kegagalan untuk berhenti merokok telah mengetahui bahaya akibat merokok, dan pernah mencoba berhenti merokok karena 
rokok mempengaruhi faktor kesehatan dan ekonomi.

Beberapa alternatif yang dapat mengalihkan perilaku merokok. Ada yang menggunakan terapi farmakologi dan terapi non-farmakologi. Beberapa obat yang digunakan untuk terapi farmakologi yaitu bupropion, vareniklin, klonidin. Namun, dari terapi farmakologi tersebut, terdapat efek samping yang ditimbulkan. Bupropion dapat menyebabkan insomnia, mulut kering, dan kejang [10]. Vareniklin dapat menyebabkan gejala gastrointestinal (mual, konstipasi, dispepsia, muntah), sakit kepala, insomnia, mimpi buruk [11]. Klonidin dapat menyebabkan mulut kering dan sedasi [12]. Faktor biaya juga merupakan masalah yang dapat ditimbulkan pada proses terapi obat untuk pemberhentian merokok. Biaya yang dikeluarkan untuk membeli obat. Terutama pada kalangan kebawah. Biaya membeli obat lebih banyak dikeluarkan daripada biaya hidup [13].

Kini banyak perokok beralih menggunakan rokok elektrik (e-cigarette) yang meningkat pesat perkembangannya. Prevelensi mantan perokok di Amerika Serikat sebagai pengguna rokok elektrik di Amerika Serikat meningkat dari 2\% pada tahun 2010 menjadi lebih dari $30 \%$ pada tahun 2012, dan kenaikan serupa terjadi di Inggris [14]. Pengguna rokok elektrik melaporkan membeli rokok elektrik untuk membantu berhenti merokok, mengurangi konsumsi rokok, dan terus ingin 'merokok', tetapi dengan risiko bahaya kesehatan berkurang [15]. Rokok elektrik terbukti memiliki potensi membantu perokok untuk berhenti atau mengurangi merokok [16]. Survei lain juga menunjukkan bahwa banyak perokok mencoba rokok elektrik karena beralasan karena rokok elektrik dapat memberikan nikotin ke dalam aliran darah dan mengurangi penggunaan tembakau, dan 13 minggu penggunaan rokok elektrik menyebabkan peningkatan untuk pantang merokok pada 6 bulan awal penggunaan ${ }^{\mathbf{1 6}}$. Selain memberikan nikotin, rokok elektrik dipercaya juga dapat mengganti kebiasaan seseorang yang terbiasa dengan memegang rokok yang akan dihisap. Rokok elektrik dapat membantu perokok untuk tetap mengkonsumsi rokok namun tanpa melalui proses pembakaran [17].

Namun penggunaan rokok elektrik sendiri masih menjadi suatu kontroversial. Oleh karena itu penelitian ini bertujuan untuk menggali lebih dalam mengenai persepsi, efektifitas dan keamanan penggunaan rokok elektrik oleh perokok aktif dalam usahanya untuk berhenti merokok.

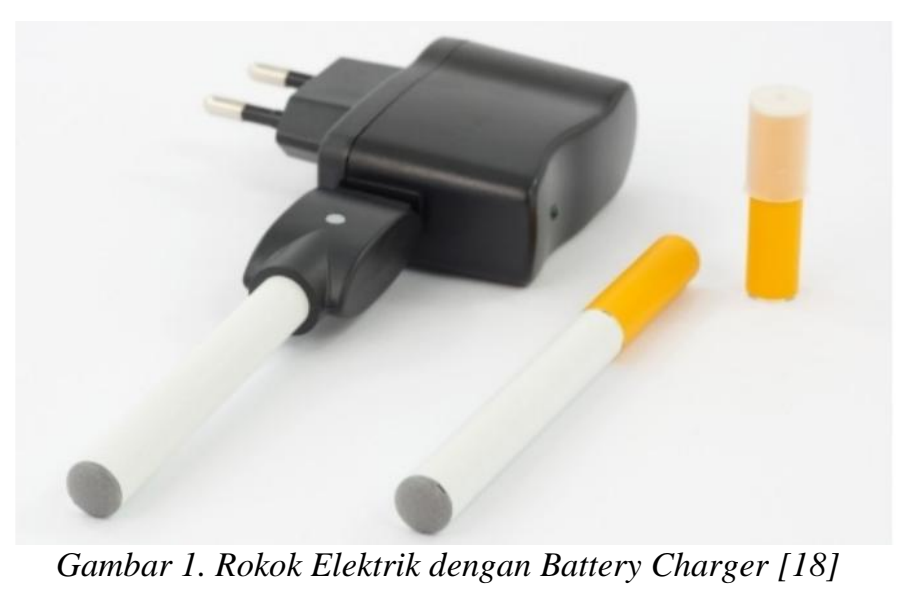




\section{METODE}

\section{Desain Penelitian}

Desain penelitian ini menggunakan model sequential explanatory, merupakan mix methods yang mengkombinasikan penelitian kuantitatif dan kualitatif secara bertahap untuk memperoleh data yang lebih komprehensif. Tahap pertama menggunakan metode deskriptif (kuantitatif) dan tahap kedua mengunakan interpretatif phenomenologi analysis (IPA) (kualitatif). Teknik pengumpulan data tahap pertama dilakukan dengan metode survey yang bertujuan untuk menilai pola penggunaan rokok elektrik, alasan menggunakan rokok elektrik, dan pendapat penggunaan rokok elektrik. Dari pertanyaanpertanyaan yang ada pada metode kuantitatif, di dalami lagi dengan menggunakan metode kualitatif supaya jawaban yang didapat lebih detail. Pada tahap kedua menggunakan IPA dengan sasarannya adalah makna berbagai pengalaman, peristiwa, status yang dimiliki oleh partisipan.

\section{Variabel Penelitian}

Variabel dalam penelitian ini meliputi: persepsi terhadap keuntungan dan kerugian, efektifitas dan keamanan.

Persepsi. Persepsi yang dimaksud dalam penelitian ini meliputi: persepsi partisipan tentang keuntungan (terkait kesehatan, ekonomi, program smoking cessation, dan pengunaan) dan kerugian (terkait kesehatan, ekonomi, program smoking cessation, dan pengunaan) dari pemakaian rokok elektrik.

Efektifitas. Efektifitas dimaksud dalam penelitian ini meliputi: Kefektifan rokok elektrik sebagai pengganti rokok dalam smoking cessation pada perokok. Data diambil dari wawancara dengan responden mengenai apakah responden sudah dapat mengurangi merokok/berhenti merokok, apakah responden merasakan perbaikan fungsi pernafasan dan kondisi lain yang pernah dialami saat menggurakan rokok biasa.

Keamanan. Keamanan dimaksud dalam penelitian ini meliputi: efek samping yang muncul setelah menggunakan rokok elektrik.

\section{Populasi Dan Sampel}

Populasi dalam penelitian ini ialah pengguna rokok elektrik di Kota Surabaya. Sampel dalam penelitian (partisipan) ini adalah pengguna rokok elektrik yang sebelumnya pernah menggunakan rokok biasa. Istilah yang digunakan untuk menggambarkan seseorang yang menghirup uap yang dihasilkan oleh rokok elektrik disebut vaper. Rokok elektrik adalah alat seperti rokok yang menghasilkan uap tanpa melalui proses pembakaran, tetapi uap yang dihasilkan dari proses penguapan hasil pemanasan dari cairan seperti propilen glikol [18]. Dalam penelitian ini teknik pengambilan sampel dengan cara snowball sampling.

\section{Metode Pengumpulan dan Analisa Data}

Proses pengumpulan data dilakukan dengan mempersiapkan peralatan, seperti pedoman wawancara, alat tulis menulis, dan perekam. Data persepsi terlebih dahulu diukur menggunakan kuesioner yang merupakan hasil modifikasi penyederhanaan dari Etter (2010) [19]., yang dilakukan dengan pertanyaan tertutup lalu dilanjutkan dengan pertanyaan terbuka dengan menggali alasan dibalik setiap persepsi yang diutarakan, serta wawancara mendalam mengenai efektifitas dan keamanan rokok elektrik. Pengambilan data menggunakan 
metode indepth interview hingga data mencapai saturasi. Teknik pengambilan data dengan menggunakan snowball sampling dan purposive sampling. Pengolahan data merupakan suatu teknik dalam penelitian kualitatif yang dilakukan setelah data lapangan terkumpul. Proses analisa data di mulai dari open coding, axial coding sampai selective coding dan pada tahap open coding dilakukan pentraskripan hasil wawancara secara verbatim yang menggambarkan proses wawancara, refleksi penelitian terhadap hasil wawancara (self reflection).

\section{HASIL DAN PEMBAHASAN}

Pengumpulan data dilaksanakan pada bulan Januari 2015 sampai Januari 2016. Sebanyak 47 orang perokok rokok elektrik yang bersedia menjadi responden. Beberapa komunitas vapor tidak bersedia dengan alasan ingin menjaga rahasia komunitasnya, takut pelangannya meninggalkan rokok elektrik, dan mengganggu pelanggan yang sedang dilayani.

\section{Karakteristik Responden}

Jenis kelamin paling banyak yang terlibat dalam penelitian ini adalah lakilaki $(95,75 \%)$ dengan usia terbesar berada di antara 17-25 tahun. Sebagian besar merupakan mantan perokok yang berarti sudah berhenti dari rokok konvensional dan beralih ke rokok elektrik $(53,19 \%)$ dan sebagian besar sebelumnya menggunakan rokok konvensional sebanyak $10-20$ batang per hari $(48,94 \%)$ (Tabel 1).

Penggunaan rokok elektrik oleh responden menunjukkan bahwa sebagian besar telah menggunakan rokok elektrik sangat lama $(53,19 \%)$ dengan frekuensi pengunaan sangat sering $(53,19 \%)$. Harga rokok elektrik yang digunakan responden beragam, dan sebagian besar mengaku menggunakan rokok elektrik dengan kisaran harga IDR 100.000 sampai kurang dari IDR 200.000 (Tabel 2).

Tabel 1. Distribusi Frekuensi Jenis Kelamin Sampel Penelitian

\begin{tabular}{llrl}
\hline & \multicolumn{2}{c}{ Karakteristik } & \multicolumn{2}{c}{ Responden (n:47) } \\
\hline Jenis kelamin & Laki-laki & 45 & $(95,75 \%)$ \\
Usia (tahun) & Perempuan & 2 & $(4,25 \%)$ \\
& $17-25$ & 46 & $(97,87 \%)$ \\
Status merokok & $26-35$ & 1 & $(2,13 \%)$ \\
& Mantan perokok & 25 & $(53,19 \%)$ \\
& Perokok Harian & 10 & $(21,28 \%)$ \\
Jumlah batang rokok per hari ${ }^{\mathbf{2 0}}$ & Sesekali merokok & 12 & $(25,53 \%)$ \\
& Ringan $(<10)$ & 18 & $(32,30 \%)$ \\
& Sedang $(10-20)$ & 23 & $(48,94 \%)$ \\
& Berat $(>20)$ & 6 & $(12,77 \%)$ \\
\hline
\end{tabular}

Tabel 2. Penggunaan Rokok Elektrik oleh Responden

\begin{tabular}{llrl}
\hline \multicolumn{2}{c}{ Penggunaan Rokok Elektrik } & Responden (n:47) \\
\hline Lama menggunakan rokok elektrik & Sangat lama & 25 & $(53,19 \%)$ \\
& Baru-baru ini & 22 & $(46,81 \%)$ \\
Penggunaan rokok elektrik dalam & Sangat sering & 25 & $(53,19 \%)$ \\
sehari & Sering & 13 & $(27,66 \%)$ \\
& Beberapa kali & 9 & $(19,15 \%)$ \\
Harga vape yang digunakan untuk & $<100.000$ & 3 & $(6,38 \%)$ \\
rokok elektrik (IDR) & 100.000 s.d <200.000 & 25 & $(53,19 \%)$ \\
& 200.000 s.d <300.000 & 13 & $(27,66 \%)$ \\
& 300.000 s.d <400.000 & 6 & $(12,77 \%)$ \\
\hline
\end{tabular}




\section{Alasan Responden Mulai Mengunakan Rokok Elektrik \\ Berdasarkan hasil mengisi} kuesioner, diketahui bahwa sebagian besar responden sangat setuju bahwa alasan memulai mengunakan rokok elektrik karena: untuk berhenti/ mengurangi merokok, menghindari mengganggu orang lain akibat asap rokok tembakau, mencari kesenangan, dan adanya adanya variasi. Dan responden juga setuju bahwa rokok elektrik dianggap lebih tidak beracun daripada rokok tembakau, lebih murah, dapat mrokok dimana-mana karena tidak ada asap rokok, penasaran, dan agar tetap mendapatkan nikotin yang dibutuhkan (Tabel 3).

Dari hasil temuan wawancara mendalam, diketahui bahwa alasan utama responden adalah demi menjaga kesehatan dan yang memperkenalkan rokok elektrik kepada responden adalah lingkungan terdekatnya. a. Beralih menggunakan vapor semenjak kualitas hidup mulai turun

b. Lingkungan merupakan pengaruh utama partisipan menggunakan vapor

\section{Persepsi Responden Mengenai Keuntungan Rokok Elektrik}

Sebagian besar persepsi responden mengenai rokok elektrik mengatakan sangat setuju bila rokok elektrik membanti mengurangi konsumsi merokok dan keuntungan tidak adanya abu dan kotoran dari rokok elektrik dibandingkan rokok tembakau (Tabel 4).

Dari hasil temuan wawancara mendalam, diketahui bahwa:

a. Terkait kesehatan

b. Terkait smoking cessation

Walaupun responden mengaku bahwa mengunakan rokok elektrik dapat mengurangi konsumsi rokok tembakau, namun rokok elektrik ternyata juga membuat efek ketagihan pada penggunanya.

Tabel 3. Jawaban Responden mengenai Alasan Mulai Menggunakan Rokok Elektrik

\begin{tabular}{|c|c|c|c|c|c|c|}
\hline \multirow{2}{*}{\multicolumn{2}{|c|}{ ALASAN PENGGUNAAN ROKOK ELEKTRIK }} & \multicolumn{5}{|c|}{ Pendapat Responden } \\
\hline & & \multirow{2}{*}{$\begin{array}{c}\text { STS } \\
0\end{array}$} & \multirow{2}{*}{$\frac{\text { TS }}{0}$} & \multirow{2}{*}{$\begin{array}{c}\mathbf{R} \\
1\end{array}$} & \multirow{2}{*}{$\frac{S}{28}$} & \multirow{2}{*}{$\frac{\text { SS }}{18}$} \\
\hline Terkait kesehatan & $\begin{array}{l}\text { Untuk kesehatan, karena menganggap rokok elektrik kurang } \\
\text { beracun dari tembakau }\end{array}$ & & & & & \\
\hline Terkait ekonomi & Lebih murah daripada rokok biasa & 4 & 12 & 11 & 16 & 4 \\
\hline Terkait program & Untuk berhenti merokok & 0 & 0 & 3 & 14 & 30 \\
\hline \multirow[t]{2}{*}{ smoking cessation } & Untuk mengurangi konsumsi rokok tembakau & 0 & 0 & 2 & 16 & 29 \\
\hline & $\begin{array}{l}\text { Sebelumnya gagal untuk berhenti merokok menggunakan } \\
\text { nikotin patch atau bupropion }\end{array}$ & 11 & 9 & 18 & 8 & 1 \\
\hline \multirow[t]{2}{*}{ Terkait penggunaan } & $\begin{array}{l}\text { Dapat merokok dimana-mana, termasuk tempat bebas asap } \\
\text { rokok }\end{array}$ & 0 & 4 & 7 & 20 & 16 \\
\hline & $\begin{array}{l}\text { Untuk menghindari mengganggu orang lain akibat asap rokok } \\
\text { tembakau yang ditimbulkan }\end{array}$ & 0 & 1 & 4 & 21 & 21 \\
\hline \multirow[t]{4}{*}{ Lain-lain } & Untuk kesenangan & 1 & 2 & 5 & 18 & 21 \\
\hline & Penasaran dengan produk baru & 2 & 3 & 8 & 26 & 8 \\
\hline & Karena rokok elektrik terdapat varian rasa dan bau yang baik & 1 & 1 & 1 & 16 & 28 \\
\hline & Agar tetap mendapatkan nikotin yang dibutuhkan & 11 & 11 & 0 & 19 & 6 \\
\hline
\end{tabular}
dan SS (sangat setuju) 
Persepsi, Efektifitas dan Keamanan Penggunaan Rokok Elektrik (E-Cigarette) oleh Perokok Aktif sebagai Terapi dalam Smoking Cessation

Tabel 4. Distribusi Frekuensi Jawaban Sampel Penelitian mengenai Keuntungan Penggunaan Rokok Elektrik

\begin{tabular}{|c|c|c|c|c|c|c|}
\hline \multirow{2}{*}{\multicolumn{2}{|c|}{ KEUNTUNGAN PENGGUNAAN ROKOK ELEKTRIK }} & \multicolumn{5}{|c|}{ Pendapat Responden } \\
\hline & & \multirow{2}{*}{$\begin{array}{c}\text { STS } \\
0\end{array}$} & \multirow{2}{*}{$\frac{\mathbf{T S}}{0}$} & \multirow{2}{*}{$\begin{array}{c}\mathbf{R} \\
1\end{array}$} & \multirow{2}{*}{$\frac{\mathbf{S}}{16}$} & \multirow{2}{*}{$\frac{\text { SS }}{30}$} \\
\hline Terkait kesehatan & $\begin{array}{l}\text { Tidak menyebabkan bau mulut dan bau yang tidak } \\
\text { menyenangkan }\end{array}$ & & & & & \\
\hline & $\begin{array}{l}\text { Batuk berkurang, dahak berkurang, sakit tenggorokan } \\
\text { berkurang }\end{array}$ & 0 & 0 & 7 & 25 & 15 \\
\hline & Pola tidur yang membaik & 1 & 5 & 10 & 21 & 10 \\
\hline & Untuk menarik napas sangat enteng & 0 & 2 & 5 & 21 & 19 \\
\hline & Kurang beracun dari asap tembakau & 0 & 2 & 9 & 20 & 16 \\
\hline & Meningkatkan pernafasan & 1 & 2 & 11 & 22 & 11 \\
\hline & Meningkatkan kesehatan dan kebugaran fisik & 0 & 2 & 20 & 16 & 9 \\
\hline \multirow[t]{2}{*}{ Terkait ekonomi } & Biaya & 2 & 14 & 6 & 22 & 3 \\
\hline & Lebih murah daripada rokok tembakau & 7 & 10 & 10 & 15 & 5 \\
\hline \multirow{3}{*}{$\begin{array}{l}\text { Terkalt program } \\
\text { smoking cessation }\end{array}$} & Keinginan untuk merokok berkurang & 1 & 0 & 3 & 16 & 27 \\
\hline & Membantu untuk berhenti merokok & 0 & 0 & 6 & 11 & 30 \\
\hline & Membantu mengurangi konsumsi rokok & 0 & 0 & 2 & 14 & 31 \\
\hline & Dapat digunakan dimana-mana & 0 & 0 & 5 & 19 & 23 \\
\hline \multirow{5}{*}{ penggunaan } & Kemudahan penggunaan & 0 & 5 & 14 & 17 & 11 \\
\hline & Gerakan yang mirip dengan merokok & 1 & 3 & 13 & 22 & 8 \\
\hline & Tidak ada asap tembakau di lingkungan sekitar & 0 & 0 & 4 & 27 & 16 \\
\hline & Tidak ada abu dan kotoran & 0 & 0 & 0 & 16 & 31 \\
\hline & Dapat memilih dosis nikotin dan jumlah puff & 0 & 0 & 2 & 20 & 25 \\
\hline
\end{tabular}

Keterangan: Pendapat responden: STS (sangat tidak setuju); TS (tidak setuju); R (ragu-ragu); S (setuju); dan SS (sangat setuju)

Tabel 5. Distribusi Frekuensi Jawaban Sampel Penelitian mengenai Kerugian Penggunaan Rokok Elektrik

\begin{tabular}{|c|c|c|c|c|c|c|}
\hline \multirow{2}{*}{\multicolumn{2}{|c|}{ KERUGIAN PENGGUNAAN ROKOK ELEKTRIK }} & \multicolumn{5}{|c|}{ Pendapat Responden } \\
\hline & & \multirow{2}{*}{$\begin{array}{c}\text { STS } \\
\text { O }\end{array}$} & \multirow{2}{*}{$\begin{array}{c}\text { TS } \\
3\end{array}$} & \multirow{2}{*}{$\begin{array}{ll}\mathbf{R} \\
\mathbf{1 3}\end{array}$} & \multirow{2}{*}{$\begin{array}{c}\mathrm{S} \\
26\end{array}$} & \multirow{2}{*}{$\frac{\mathbf{S S}}{5}$} \\
\hline Terkait kesehatan & Tidak ada efek yang tidak diinginkan & & & & & \\
\hline & Mulut dan tenggorokan kering & 5 & 14 & 14 & 10 & 4 \\
\hline & Vertigo, sakit kepala, mual & 16 & 21 & 6 & 4 & $\mathbf{0}$ \\
\hline & Masala berat badan & 16 & 22 & 5 & 4 & $\mathbf{0}$ \\
\hline & $\begin{array}{l}\text { Tidak ada studi atau informasi tentang komposisi } \\
\text { uap dan risiko kesehatan rokok elektrik }\end{array}$ & 2 & 21 & 16 & 5 & 3 \\
\hline Terkait ekonomi & Terlalu mahal & 3 & 10 & 12 & 19 & 3 \\
\hline $\begin{array}{l}\text { Terkait program } \\
\text { smoking cessation }\end{array}$ & $\begin{array}{l}\text { Sulit untuk berhenti menggunakan rokok elektrik } \\
\text { tanpa kambuh untuk merokok }\end{array}$ & 8 & 20 & 4 & 13 & 2 \\
\hline \multirow[t]{8}{*}{ Terkait penggunaan } & Sulit mengontrol secara akurat dosis nikotin & 13 & 17 & 9 & 6 & 2 \\
\hline & $\begin{array}{l}\text { Kualitas buruk, kurang diandalkan dan sering } \\
\text { kegagalan }\end{array}$ & 5 & 19 & 17 & 5 & 1 \\
\hline & Baterai terlalu cepat abis & $\mathbf{0}$ & 7 & 7 & 25 & 8 \\
\hline & Rasa tidak enak & 16 & 25 & 3 & 3 & $\mathbf{0}$ \\
\hline & Cairan dapat bocor selama pemakaian & 4 & 12 & 16 & 12 & 3 \\
\hline & Tidak praktis dan dosis sulit untuk disesuaikan & 6 & 18 & 10 & 9 & 4 \\
\hline & Hanya dijual di internet & 19 & 19 & 2 & 5 & 2 \\
\hline & Terlalu besar atau terlalu berat & 4 & 22 & 8 & 9 & 4 \\
\hline
\end{tabular}

Keterangan: Pendapat responden: STS (sangat tidak setuju); TS (tidak setuju); R (ragu-ragu); S (setuju); dan SS (sangat setuju) 
Tabel 6. $\quad$ Distribusi Frekuensi Efektifitas Penggunaan Rokok Elektrik

\begin{tabular}{lcc}
\multicolumn{1}{c}{ Frekuensi Merokok } & \multicolumn{2}{c}{ Responden (n:12) } \\
\hline Berhenti merokok tembakau & 9 & $(75,00 \%)$ \\
Berkurang merokok tembakau & 3 & \\
Dari 16 batang/hari menjadi 1 batang/ hari & 1 & $(25,00 \%)$ \\
Dari 16 batang/hari menjadi 2 batang/ hari & 1 & \\
Dari 25 batang/hari menjadi 5 batang/ hari & 1 & \\
Tetap & 0 & $(0,00 \%)$ \\
\hline
\end{tabular}

\section{Persepsi Responden Mengenai Kerugian Rokok Elektrik}

Sebagian besar responden tidak setuju bila rokok elektrik dianggap dapat mengganggu kesehatan, tidak bermanfaat dalam smoking cessation, dan penggunaan yang lebih susah dibanding rokok tembakau. Selain itu dari segi penggunaannya, rokok elektrik juga ternyata boros baterai sehingga menyulitkan penggunannya. Namun dari segi biaya, sebagian responden setuju bila rokok elektrik lebih mahal daripada rokok tembakau (Tabel 5).

Setelah mengetahui dampak negatif dari kebiasan merokok terutama masalah kesehatan, seseorang akan berfikir ulang untuk melakukan pemberhentian merokok atau biasa disebut smoking cessation. Munculnya gangguan kesehatan yang dialami seorang perokok menyebabkan ketidak nyamanan ketika merokok, seperti lidah yang terasa pahit, dada terasa nyeri, hipertensi, dan sakit kepala. Gejala yang timbul tersebut menjadi titik balik seseorang untuk mendapatkan kualitas hidup yang baik dengan melakukan smoking cessation atas dasar kesadaran dan keinginan yang kuat [21]. Selain itu ada beberapa alasan lain sehingga perokok tetap merokok, seperti karena pengaruh anggota keluarga yang merokok, untuk mengontrol berat badan, membantu mengatasi stress, dan pengaruh lingkungan sosial [9].

Kecanduan atau keinginan untuk terus merokok disebabkan kandungan nikotin dalam rokok yang memberikan efek adiktif [3],[8]. Efek nikotin dapat menimbulkan kecanduan dikarenakan adanya interaksi antara nikotin dengan reseptor kolinergik nikotin di otak yaitu Nicotinic Acetylcholine Receptors (nAChRs) di daerah mesolimbik dopamin system di Ventral Tegmental Area (VTA) neuron yang mengawali aktivasi Central Nervus System (CNS) termasuk system Mesoaccumbens Dopamin. Reseptor nikotinin mengatur pelepasan dopamin. Nikotin mengubah aktivitas VTA untuk meningkatkan sekresi dopamine. Dopamin yang dilepaskan berperan dalam pengontrolan fungsi aktivitas lokomotorik kognisi, emosi, reinsformenpositif, serta regulasi endokrin. Akibat dari pelepasan dopamine, maka akan timbul perasaan nyaman bagi perokok [22-23].

Hambatan umum yang lain adalah tingkat stres yang dialami, kurang dukungan dari tenaga kesehatan dan penyedia layanan, dan prevalensi tinggi dan akseptabilitas mreokok yang rentan di masyarakat. Hambatan yang unik diidentifikasi untuk orang yang pengidap gangguan mental, kelompok adat, tahanan, orang yang kehilangan tempat tinggal, dan pada pemuda yang menerapkan lifestyle [24].

\section{Efektitas Rokok Elektrik}

Data efektifitas penggunaan vapor dikumpulkan melalui wawancara terbuka, dan dari 47 sampel penelitian hanya 12 orang yang bersedia untuk mengikuti wawancara mendalam lebih lanjut. Efektifitas penggunaan rokok elektrik 
dinilai dari penurunan frekuensi penggunaan rokok biasa (rokok tembakau). Dari 12 sampel penelitian yang diwawancara, sebagian besar sampel penelitian mengalami berhenti merokok tembakau $(75 \%)$ dan tidak ada yang tidak memberikan efek (Tabel 6).

Kelebihan rokok elektrik

dibandingkan dengan rokok konvesional adalah memiliki efek yang bermanfaat bagi kesehatan seperti meningkatkan toleransi latihan dan sedikit menimbulkan batuk. E-cigarette juga tidak menimbulkan bau rokok atau bau nafas dan lebih tidak toksik daripada rokok konvensional. Pada perokok konvensional yang beralih ke e-cigarette menimbulkan sensasi di tenggorokan yang mirip dengan merokok konvensional dan penggunaannya mirip dengan merokok pada umumnya sehingga tidak dapat mempermudah pemberhentian merokok konvensional. Selain itu, ter dapat juga klaim bahwa merokok e-cigarette tidak perlu menggunakan fasilitas merokok dan meredakan gejala withdrawal dari rokok konvensional [17].

Tetap saja rokok elektrik memiliki kekurangan seperti pada beberapa orang sensitif terhadap propylene glycol seperti mulut dan tenggorokan kering, beberapa rasa memiliki bau yang menetap, pada beberapa produk terdapat sisa kontaminan dan logam sehingga cukup berbahaya, rokok elektrik lebih berat daripada rokok konvensional, puffing techniquememerlukan latihan, tidaksemua orang mengurangi konsumsi rokok konvensional walaupun tujuan rokok elektrik adalah untuk menekan konsumsi rokok konvensional [17].

Responden berpendapat bahwa dengan menggunakan rokok elektrik keinginan untuk mengkonsumsi rokok tembakau dapat ditahan, mengurangi konsumsi rokok dan ketergantungan pada rokok tembakau. Terdapat penelitian yang menjelaskan bahwa dari beberapa perokok yang berusaha untuk berhenti, mereka yang menggunakan rokok elektrik merasa lebih dapat menahan keinginan mereka untuk berhenti merokok daripada yang tidak menggunakan rokok elektrik [14]. Rokok elektrik juga mengurangi konsumsi rokok dan mengurangi ketergantungan perokok pada tembakau [15-17].

Selain itu, responden juga berpendapat bahwa setelah beberapa hari atau sudah lama menggunakan rokok elektrik, pernafasan menjadi sangat lancar. Nyeri dada yang sering dikeluhkan oleh partisipan pada saat mengkonsumsi rokok tembakau suda tidak kambuh lagi ketika beralih menggunakan rokok elektrik. Pendapat tersebut diperkuat dengan penelitian sebelumnya yang menyatakan bahwa rokok elektrik tidak memiliki efek negatif langsung pada sistem kardiovaskular dan fungsi jantung [25]. Pendapat lain dari salah satu partisipan juga menyatakan bahwa setelah menggunakan vapor dalam beberapa hari atau sudah lama menggunakan, kebugaran tubuh partisipan menjadi membaik. Untuk melakukan aktivitas yang berat seperti olahraga nafas sudah tidak sesak lagi. Pernyataan tersebut diperkuat dengan survei yang menyatakan lebih dari 19000 vaper menemukan bahwa hampir $75 \%$ responden melaporkan bahwa mereka merasa lebih sehat setelah beralih ke rokok elektrik dari rokok tembakau contohnya seperti stamina, pernapasan, indra perasa, indra penciuman [26]. Ada juga yang berpendapat bahwa $95 \%$ dari responden dalam survei secara online melaporkan bahwa kesehatan mereka, kemampuan berolahraga, dan indra perasa menjadi lebih baik sejak penggunaan rokok elektrik [27]. 
Beberapa penelitian telah menunjukkan bahwa, pada perokok akut memiliki efek samping yang signifikan pada ventrikel kiri sebagai fungsi miokard yang dapat dideteksi dengan ekokardiografi [26, 28-29]. Meskipun gangguan pernapasan perokok akut disebabkan kerterlambatan dalam relaksasi miokard ventrikel kiri, pada penggunaan rokok elektrik ditemukan memiliki efek berbeda. Riwayat penggunaan rokok elektrik lebih menguntungkan dibandingkan dengan merokok. Meskipun tidak menentukan tentang efek kesehatan secara keseluruhan sebagai produk pengurangan dampak buruk tembakau, dapat memberikan bukti tentang efek kardiovaskular dari perangkat ini [25]. Dari berbagai penelitian yang dilakukan menyimpulkan bahwa asap rokok elektrik tidak meninggalkan racun pembakaran seperti pada rokok tembakau. Hanya meninggalkan jejak nikotin saja [30]. Ada beberapa studi yang telah menguji efek akut bekas paparan uap rokok elektrik. Seperti yang di teliti oleh Flouris et al. [31], menemukan bahwa perokok pasif rokok elektrik tidak mempengaruhi darah pada subyek manusia.

Tabel 7. Distribusi Frekuensi Efektifitas Penggunaan Rokok Elektrik

\begin{tabular}{lc}
\multicolumn{1}{c}{ Efek yang diduga ditimbukan rokok elektrik } & Responden (n:12) \\
\hline Tenggorokan kering dan batuk & 4 \\
Tidak mengalami efek samping & $83,33 \%)$ \\
\hline
\end{tabular}

\section{Keamanan Rokok Elektrik}

Data keamanan rokok elektrik yang dikumpulkan dari wawancara dengan 12 sampel penelitian menunjukan bahwa hanya tenggorokan kering dan batuk $(33,33 \%)$ yang dialami penggun rokok elektrik (Tabel 7).

Rokok elektrik adalah produk yang dirancang untuk dapat memberikan nikotin atau zat lain ke pengguna dalam bentuk uap. Terdiri dari tempat isi ulang, baterai untuk mengoperasikan bagian pemanas, dan alat penyemprot yang ketika dipanaskan mengubah cairan menjadi uap. Uap ini yang kemudian dapat dihirup oleh pengguna [32]. Rokok elektrik terlihat dan berfungsi seperti rokok konvensional biasa, akan tetapi tidak membakar sejumlah tembakau. Rokok elektrik secara umum memiliki baterai dan perangkat elektronik yang memproduksi asap atau semacam kabut. Kandungannya selalu berisi nikotin tetapi ada juga yang tidak memiliki kandungan nikotin sama sekali dan berisi propilen glikol.

a. Asap.

Asap yang dihasilkan rokok elektrik dihirup sebagaimana layaknya merokok konvensional dan sejumlah asap dilepaskan tetapi berupa asap rokok. Beberapa jenis rokok elektrik juga mempunyai sejenis lampu kecil yang akan menyala pada saat rokok elektrik dihisap, memyerupai pembakaran yang terjadi pada rokok konvensional.

Uap yang dihasilkan dari rokok elektrik, didapat dari cairan yang dipanaskan. Cairan tersebut mengandung berbagai komposisi seperti nikotin, air, aditif, perasa. Pelarut yang digunakan yang paling populer adalah gliserin (VG), propilen glikol (PG), atau kombinasi gliserin dan propilen glikol dengan perbandingan dengan perbandingan tertentu [33]. Meskipun jumlah bahan kimia berbahaya yang ditemukan di rokok elektrik lebih sedikit dibandingkan rokok konvensional atau yang biasa disebut rokok tembakau, kromium dan 
nikel ditemukan empat kali lipat dalam beberapa jenis rokok elektrik yang tidak ada di rokok tembakau [34].

\section{b. Catridge.}

Cartridge dapat selalu diisi ulang dan isi ulang tersebut merupakan begian dari perangkat rokok elektrik [18]. Cartridge pada rokok elektrik berisi sintesis nikotin yang terlarut di dalam propilen glikol, air dan zat pemberi rasa, selain itu terdeteksi pula bahan tambahan berupa diethilen glikol (komponen anti pembekuan dan bersifat toksis pada manusia) dan nitrosamin (zat bersifat karsinogen) pada setengah dari sampel penelitian [35].

\section{c. Baterai.}

Demikian pula halnya dengan baterai yang dimiliki oleh rokok elektrik, merupakan suatu baterai yang dapat diisi ulang kembali [35] dan saat dioperasikan, akan timbul panas yang dihasilkan oleh tenaga baterai yang selanjutnya akan memanaskan sejumlah cairan yang tersimpan di dalam cartridge untuk memproduksi asap yang akan dihisap oleh pengguna [36].

Terdapat penelitian yang menyatakan keamanan rokok elektrik tidak terjamin. Liquid rokok elektrik dan voltase pada baterai yang ada pada rokok elektrik memiliki komponen yang berbahaya. Dan akan semakin berbahaya yang memiliki tegangan yang tinggi. Dikarenakan dapat menimbulkan percikapan api bahkan ledakan [33]. Pendapat tersebut sejalan dengan pendapat partisipan yang ada pada penelitian ini. Salah satu partisipan pada penelitian ini menyatakan memiliki pengalaman yang buruk ketika rokok elektrik yang dimilikinya secara langsung mengeluarkan percikan api. Karena oleh partisipan rokok elektrik tersebut di setting dengan tegangan tinggi yang dapat menghasilkan panas yang tinggi pula yang dapat menghasilkan asap yang sangat banyak.

Diperkirakan bahwa suhu penguapan teoritis dapat mencapai $350^{\circ} \mathrm{C}$ [37-38]. Suhu yang tinggi ini dapat mendorong perubahan fisik cairan rokok elektrik dan reaksi kimia antara konstituen dari cairan rokok elektrik. Pada suhu ini, pelarut dapat mengalami dekomposisi termal menyebabkan pembentukan senyawa yang berpotensi beracun. VG dan PG telah terbukti terurai pada suhu tinggi menghasilkan senyawa karbonil yang bersifat toksik, misalnya formaldehida, asetaldehida, akrolein, dan aseton [39].

d. Beberapa bahan yang merupakan komponen spesifik tembakau yang bersifat berbahaya bagi manusia (anabasine, myosamine, dan betanycotyrine) juga terdeteksi pada kandungan rokok elektrik [35].

\section{KESIMPULAN}

Beberapa hal yang dapat ditarik kesimpulan dalam penelitian ini adalah:

1. Partisipan menganggap rokok elektrik dapat membantu dalam proses berhenti merokok (smoking cessation). Ketika menggunakan rokok elektrik partisipan merasa keinginan untuk merokok tembakau sudah berkurang dan semakin hilang.

2. Rokok elektrik terbukti dapat mengurangi responden merokok dengan rokok tembakau $(25 \%)$ dan bahkan sebesar $75 \%$ berhenti merokok.

3. Keamanan rokok elektrik bagi kesehatan yang baru dilaporkan adalah sebatas tenggorokan terasa kering dan batuk (33,33\%), selebihnya tidak mengalami efek samping $(66,66 \%)$. 


\section{REFERENSI}

[1]. GATS. (2012). Global Adult Tobacco Survey: Fact Sheet Indonesia Report 2011. National Institute of Health Research and Development and World Health Organization.pp1-2.

[2]. Peraturan Pemerintah No. 19 Tahun 2003 tentang Pengamanan Rokok Bagi Kesehatan

[3]. CDC (Centre for Disease Control and Preventio). 2014. SMOKING AND CARDIOVASCULAR DISEASE. https://www.cdc.gov/tobacco/data_statistic $\mathrm{s} / \mathrm{sgr} / 50$ th-

anniversary/pdfs/fs_smoking_CVD_508.p df

[4]. Global Obstructive Lung Disease (GOLD), 2016, Global Initative for Chronic Obstructive Lung Disease (Update).

[5]. Badan Pusat Statistik Indonesia. (2017. Rokok vs. Kemiskinan. https://www.bps.go.id/KegiatanLain/view/i d/133

[6]. Rigotti NA, Pipe AL, Benowitz NL, Arteaga C, Garza D, Tonstad S. 2010. Efficacy and safety of varenicline for smoking cessation in patients with cardiovascular disease: a randomized trial. Circulation. 2010 Jan 19;121(2):221-9.

[7]. Sadikin ZD, Lousia M, 2011. Program Berhenti Merokok. Majalah Kedokteran Indonesia. 58(4):130-137.

[8]. Berrendero F., Robledo P., Trigo J. M., Martín-García E., Maldonado R. (2010). Neurobiological mechanisms involved in nicotine dependence and reward: participation of the endogenous opioid system. Neurosci. Biobehav. Rev. 35, 22023110.1016/j.neubiorev.2010.02.006

[9]. Lorensia A., Yudiarso A, Pratama AM. 2016. Interpretative Phenomenological Analysis: Pharmacy Student Perceptions of Cigarette Smoking of Health Awareness in Smoking Cessation. Jurnal ANIMA Indonesian Psychological Journal, UBAYA, July 2016. 31(4):170-179 (ISSN0215-0158).

[10]. Wilkes, 2008. The use of bupropion SR in cigarette smoking cessation. Int J Chron Obstruct Pulmon Dis. 2008 Mar; 3(1): 4553.

[11]. Fagerström K, Hughes J. Varenicline in the treatment of tobacco dependence.
Neuropsychiatr Dis Treat. 2008 Apr; 4(2): 353-363.

[12]. Gourlay SG, Stead LF, Benowitz N. Clonidine for smoking cessation. Cochrane Database of Systematic Reviews 2004, Issue 3. Art. No.: CD000058. DOI: 10.1002/14651858.CD000058.pub2.

[13]. Prades JLP, Abellán-Perpiñán JM, Méndez-Martínez I, Díaz-Cerezo S, Burgoa VS. 2011. Working Papers from Universidad Pablo de Olavide, Department of Economics.

[14]. Jamie Brown, Emma Beard, Daniel Kotz, Susan Michie \& Robert West, 2014, RealWorld Effectiveness of E-Cigarettes When Used To Aid Smoking Cessation: A CrossSectional Population Study.

[15]. Caponnetto P, Campagna D, Cibella F, Morjaria JB, Caruso M, Polosa R, 2013, Efficiency And Safety of an Electronic Cigarette as Tobacco Cigarette Substitute: A Prospective 12-Moth Randomized Control Design Study.

[16]. Bullen C, McRobbie H, Thornley S, et al., 2010, Effect of an Electronic Nicotine Delivery Device (E-Cigarette) on Desire to Smoke and Nicotine Delivery: Randomised Cross-Over Trial.

[17]. Polosa R, Caponnetto P, Morjaria JB, Papale G, Campagna D, Russo C, 2011, Effect Of an Electronic Nicotine Delivery Device(E-Cigarette) on Smoking Reduction and Cessation: A Prospective 6Month Pilot Study.

[18]. Erbach G. Electronic Cigarettes. Library of the European Parliament. 2013:130494REV2:1-8

[19]. Etter JF. 2010. Electronic cigarettes: a survey of users. BMC Public Health 2010, 10:231

[20]. Bustan M.N. Epidemiologi Penyakit Tidak Menular. Edisi Kedua. Jakarta : Rineka Cipta.2007

[21]. Nurhidayati F, Triratnawati A. Smoking Cessation Therapy. Makara Journal of Health Research. 2005;9(1):15-22

[22]. D'Souza MS, Markou A. Neuronal Mechanisms Underlying Development of Nicotine Dependence: Implications for Novel Smoking-Cessation Treatments. Addict Sci Clin Pract 2011 Jul; 6(1): 4-16

[23]. Gotti C, Guiducci S, Tedesco V, Corbioli S, Zanetti L, Moretti M, Zanardi A, Rimondini R, Mugnaini M, Clementi F, Chiamulera C, Zoli M. Nicotinic acetylcholine receptors in the mesolimbic pathway: primary role of ventral tegmental 
area alpha6beta $2 *$ receptors in mediating systemic nicotine effects on dopamine release, locomotion, and reinforcement. J Neurosci. 2010 Apr 14;30(15):5311-25

[24]. Twyman L, Bonevski B, Paul C, Bryant J. Perceived barriers to smoking cessation in selected vulnerable groups: a systematic review of the qualitative and quantitative literature. BMJ Open. 2014;4:e006414

[25]. Farsalinos KE, Tsiapras D, Kyrzopoulus S, Sawopoulu M, Voudris V, 2014, Acute Effects Of Using An Electronic Nicotine Delivery Device (Electronic Cigarette) On Myocardial Function: Comparison With The Effects Of Regular Cigarettes. BMC Cardiovasc Disord. 2014 Jun 23;14:78.

[26]. Farsalinos KE, Romagna G, Tsiapras D, Kyrzopoulus S, Voudris V. 2014, Characteristics, Perceived Side Effect And Benefits Of Electronic Cigarette Use: A Worldwide Survey Of More Than 19000 Consumers. Int. J. Environ. Res. Public Health 2014, 11(4), 4356-4373

[27]. Heavner K, Dunworth J, Bergen P, Nissen C, Carl V. Phillips, 2009, Electronic Cigarettes (E-Cigarettes) as Potential Tobacco Harm Reduction Products : Results of an Online Survey of E-Cigarette Users.

(http://www.tobaccoharmreduction.org/wp apers/electronic.pdf)

[28]. Lichodziejewska B, Kurnicka k, grudzka $\mathrm{k}$, et al., 2007. Chronic and acute effects of smoking on left and right ventricular relaxation in young healthysmokers. CHEST. 131:1142-1148

[29]. Karakaya O, Barutcu I, MD, Esen AM, Kaya D, Turkmen M, Melek M, et al. Acute Smoking-Induced Alterations in Doppler Echocardiographic Measurements in Chronic Smokers. Tex Heart Inst J. 2006; 33(2): 134-138.

[30]. Czogala J, Goniewicz ML, Fidelus B, Zielinska-Danch W, Travers MJ, Sobczak A. Secondhand Exposure to Vapor from Electronic Cigarettes. Nicotine Tob Res. 2014 Jun;16(6):655-62
[31]. Flouris AD, Poulianiti KP , Chorti MS, Jamurtas AZ, Kouretas D, Owolabi EO, Tzatzarakis MN, Tsatsakis AM, Koutedakis Y. Acute effects of electronic and tobacco cigarette smoking on complete blood count. Food and Chemical Toxicology 50 (2012) 3600-3603

[32]. McEwen A, McRobbie H. Electronic cigarettes: A briefing for stop smoking services. National Centre for Smoking Cessation and Training (NCSCT). 2016

[33]. Kosmider L, Sobczak A, Filk M, Knysak J, Zaciera M, Kurek J, Goniewicz ML, 2014, Carbonyl Compounds in Electronic Cigarette Vapor Effects of Nicotine Solvent and Battery Output Voltage. Nicotine Tob Res. 2014 Oct;16(10):131926.

[34]. Perkins R. E-cigarette smoke found to contain toxic metals. Usc news https://news.usc.edu/67718/e-cigarettesmoke-found-to-contain-toxic-metals/

[35]. Westenberger B.J. Evaluation of ecigarettes. Department of Health \& Human Services Food and Drug and Drug Administration. 2009: DPATR-FY-09-23

[36]. Wollscheid, K. A., \& Kremzner, M. E. (2009). Electronic cigarettes: Safety concerns and regulatory issues. American Journal of Health-System Pharmacy, 66(19), 1740-1742

[37]. Talih S, Balhas Z, Salman R, Karaoghlanian N, Shihadeh A. "Direct Dripping": A High-Temperature, HighFormaldehyde Emission Electronic Cigarette Use Method. Nicotine Tob Res. 2016 Apr;18(4):453-9

[38]. Schripp T, Markewitz D, Uhde E, Salthammer T. 2012. Does E-Cigarette Consumption Cause Passive Vaping? Indoor Air. 2013 Feb;23(1):25-31

[39]. Paschke A, Scherer G, Heller WD (2002) Effects of ingredients on cigarette smoke composition and biological activity: A literature overview. Tobacco Research 20.

How to cited this article :

Lorensia A, Yudiarso A, Rafsanjani F Herwansyah. 2017. Persepsi, Efektifitas dan Keamanan Penggunaan Rokok Elektrik (E-Cigarette) oleh Perokok Aktif sebagai Terapi dalam Smoking Cessation: Mixed Methods dengan Pendekatan Studi Kuantitatif dan Kualitatif, J. Trop. Pharm. Chem. (4)2; 66-78. 